\title{
Using a Tailored Digital Health Intervention for Family Communication and Cascade Genetic Testing in Swiss and Korean Families With Hereditary Breast and Ovarian Cancer: Protocol for the DIALOGUE Study
}

Sue Kim ${ }^{1}$, PhD; Monica Aceti ${ }^{2}$, PhD; Vasiliki Baroutsou ${ }^{2}$, MSc; Nicole Bürki ${ }^{3}$ MD, PhD; Maria Caiata-Zufferey ${ }^{4}$, $\mathrm{PhD}$; Marco Cattaneo ${ }^{2}, \mathrm{PhD}$; Pierre O Chappuis ${ }^{5}, \mathrm{MD}$; Florina M Ciorba ${ }^{6}, \mathrm{PhD}$; Rossella Graffeo-Galbiati ${ }^{7}, \mathrm{MD}$; Viola Heinzelmann-Schwarz ${ }^{3}$, MD; Joon Jeong ${ }^{8}$, MD, PhD; MiSook M Jung ${ }^{9}$, PhD; Sung-Won Kim ${ }^{10}$, MD, PhD, FACS; Jisun Kim ${ }^{11}$, MD, PhD; Myong Cheol Lim ${ }^{12}$, MD, PhD; Chang Ming ${ }^{2}$, MSc, PhD; Christian Monnerat ${ }^{13}$, MD; Hyung Seok Park ${ }^{8}$, MD, PhD; Sang Hyung Park ${ }^{14}$, PhD; Carla A Pedrazzani ${ }^{2}$, MSN; Manuela Rabaglio ${ }^{15}$, MD; Jai Min Ryu ${ }^{16}$, MD, PhD; Ramon Saccilotto ${ }^{2}$, MD; Simon Wieser ${ }^{17}$, PhD; Ursina Zürrer-Härdi ${ }^{18}$, MD; Maria C Katapodi ${ }^{2}$, $\mathrm{PhD}$

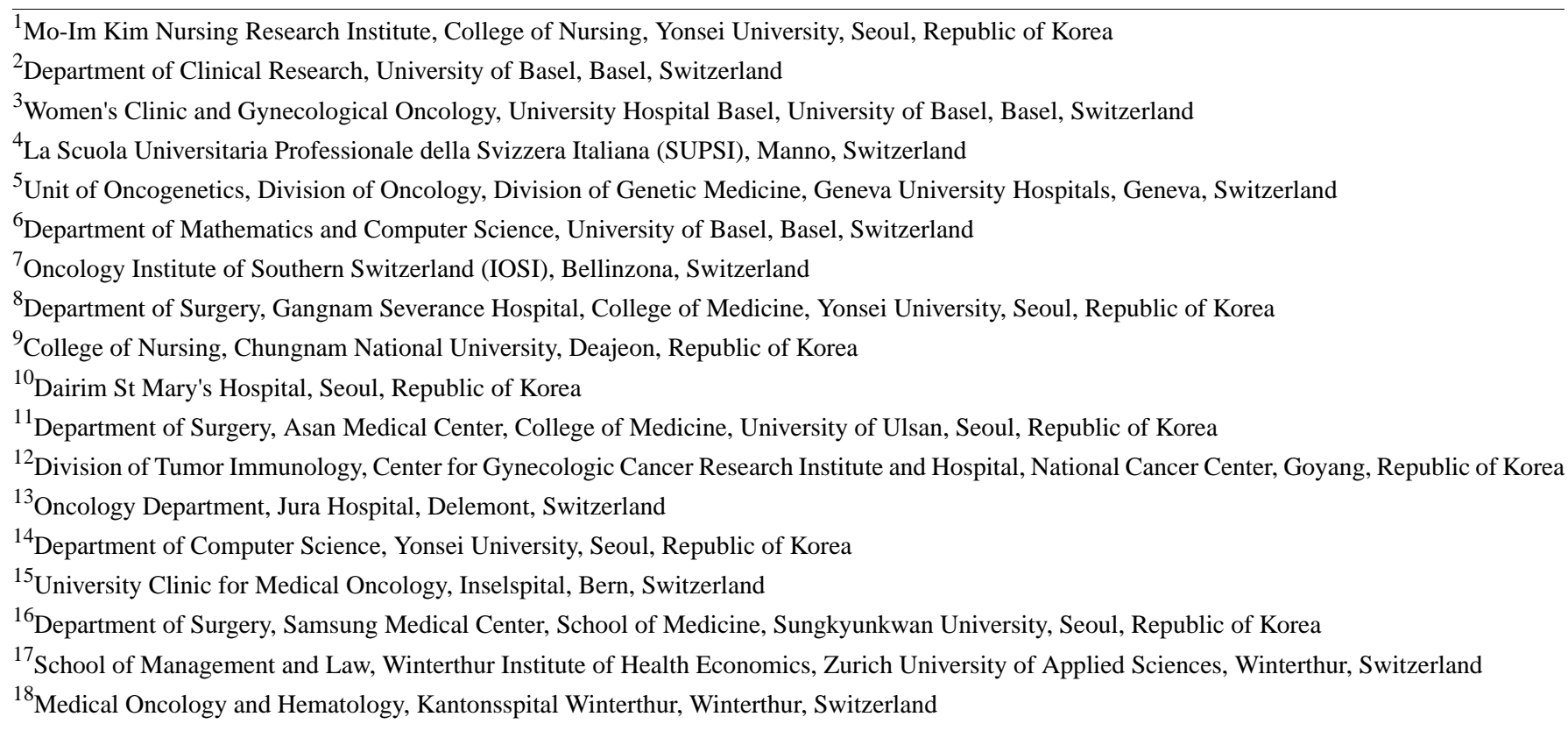

\section{Corresponding Author:}

Maria C Katapodi, PhD

Department of Clinical Research

University of Basel

Missionstrasse 64

Basel, 4055

Switzerland

Phone: 41612070430

Fax: 41612076155

Email: maria.katapodi@unibas.ch

\section{Abstract}

Background: In hereditary breast and ovarian cancer (HBOC), family communication of genetic test results is essential for cascade genetic screening, that is, identifying and testing blood relatives of known mutation carriers to determine whether they also carry the pathogenic variant, and to propose preventive and clinical management options. However, up to $50 \%$ of blood 
relatives are unaware of relevant genetic information, suggesting that potential benefits of genetic testing are not communicated effectively within family networks. Technology can facilitate communication and genetic education within HBOC families.

Objective: The aims of this study are to develop the K-CASCADE (Korean-Cancer Predisposition Cascade Genetic Testing) cohort in Korea by expanding an infrastructure developed by the CASCADE (Cancer Predisposition Cascade Genetic Testing) Consortium in Switzerland; develop a digital health intervention to support the communication of cancer predisposition for Swiss and Korean HBOC families, based on linguistic and cultural adaptation of the Family Gene Toolkit; evaluate its efficacy on primary (family communication of genetic results and cascade testing) and secondary (psychological distress, genetic literacy, active coping, and decision making) outcomes; and explore its translatability using the reach, effectiveness, adoption, implementation, and maintenance framework.

Methods: The digital health intervention will be available in French, German, Italian, Korean, and English and can be accessed via the web, mobile phone, or tablet (ie, device-agnostic). K-CASCADE cohort of Korean HBOC mutation carriers and relatives will be based on the CASCADE infrastructure. Narrative data collected through individual interviews or mini focus groups from 20 to 24 HBOC family members per linguistic region and 6-10 health care providers involved in genetic services will identify the local cultures and context, and inform the content of the tailored messages. The efficacy of the digital health intervention against a comparison website will be assessed in a randomized trial with 104 HBOC mutation carriers (52 in each study arm). The translatability of the digital health intervention will be assessed using survey data collected from HBOC families and health care providers.

Results: Funding was received in October 2019. It is projected that data collection will be completed by January 2023 and results will be published in fall 2023.

Conclusions: This study addresses the continuum of translational research, from developing an international research infrastructure and adapting an existing digital health intervention to testing its efficacy in a randomized controlled trial and exploring its translatability using an established framework. Adapting existing interventions, rather than developing new ones, takes advantage of previous valid experiences without duplicating efforts. Culturally sensitive web-based interventions that enhance family communication and understanding of genetic cancer risk are timely. This collaboration creates a research infrastructure between Switzerland and Korea that can be scaled up to cover other hereditary cancer syndromes.

Trial Registration: ClinicalTrials.gov NCT04214210; https://clinicaltrials.gov/ct2/show/NCT04214210 and CRiS KCT0005643; https://cris.nih.go.kr/cris/

International Registered Report Identifier (IRRID): PRR1-10.2196/26264

(JMIR Res Protoc 2021;10(6):e26264) doi: 10.2196/26264

\section{KEYWORDS}

HBOC; proportion of informed at-risk relatives; coping; communicating; decisional conflict; cultural and linguistic adaptation; implementation; RE-AIM; mobile phone

\section{Introduction}

\section{Background}

In 2018, there were approximately 2.1 million breast cancer diagnoses and more than 600,000 associated deaths worldwide $[1,2]$. The worldwide average breast cancer incidence is 74.2 per 100,000 women [3], with approximately $25 \%$ of cases occurring in women younger than 50 years and in women with a family history of cancer [4,5]. Approximately 5\%-10\% of breast cancer and $20 \%$ of ovarian cancer cases occur due to germline pathogenic variants associated with hereditary breast and ovarian cancer (HBOC) syndrome, most commonly observed in the BRCA-1 and BRCA-2 genes (hereafter BRCA). The prevalence of germline pathogenic variants differs among ethnic groups [6]; however, Switzerland and Korea have a similar prevalence ranging from $23 \%$ to $26 \%[7,8]$.

The availability of genetic services (counseling and testing) for actionable hereditary cancer syndromes such as HBOC enables population-level cancer prevention [9]. Blood relatives of HBOC cases have a $12.5 \%-50 \%$ probability of inheriting the same pathogenic variant and can be tested with $100 \%$ accuracy. Chemoprevention, prophylactic surgery, and intensive surveillance can lower cancer risks for relatives who test positive, whereas those who test negative are excluded from these interventions [10-12]. The Centers for Disease Control and Prevention Office for Public Health Genomics recommend genetic testing in cancer-free individuals with a known HBOC family history and in patients with cancer who have strong indications of HBOC syndrome (eg, ovarian cancer) [13]. Cascade genetic screening is a systematic effort to identify and test all blood relatives of $\mathrm{HBOC}$ cases to determine whether they also carry the same pathogenic variant [10]. The CASCADE (Cancer Predisposition Cascade Genetic Testing) Consortium in Switzerland promotes cascade genetic screening for HBOC [14,15], whereas the Korean Hereditary Breast Cancer (KOHBRA) network identifies the prevalence of HBOC-associated pathogenic variants in the Korean population [16,17].

Despite calls to action for HBOC cascade genetic testing, there are systemic barriers to its implementation. Privacy laws worldwide, including Switzerland and Korea, restrict health care providers from revealing genetic information to anyone except the tested individual, who has the right not to disclose this information, despite implications for relatives' health 
[18-20]. The potential benefits of genetic testing are not being effectively communicated through family networks, leading to more than $50 \%$ of at-risk individuals not using genetic services and not receiving important information from a credible source [21-23]. Second-degree and male relatives, those living further away, and those with an estranged relationship with the mutation carrier are most likely not to be informed about genetic testing $[24,25]$. Despite these difficulties, a family-based approach in communicating hereditary cancer risk is advantageous because it may reach relatives through the social bonds and functions already existing within the family network, and it is not limited to those in contact with the health care system [26].

Interventions that support mutation carriers during the disclosure of genetic test results can reduce psychological distress and provide relatives with accurate and credible information about cascade genetic testing. Technology-enabled education is not inferior to face-to-face genetic consultations [27,28], but it increases access to services and cost-effectiveness [29-32]. The Family Gene Toolkit [33] is a web-based intervention designed to increase prerequisites for HBOC cascade testing, that is, active coping, open family communication, and informed decision making. The prototype Family Gene Toolkit was tested in the United States for acceptability and patient satisfaction with excellent results, confirming its value for these families. However, it is not available in other linguistic and cultural contexts. Adapting existing interventions, rather than developing new ones, takes advantage of the previous valid experiences without duplicating efforts.

In summary, HBOC cascade genetic testing, meaning the identification and testing of blood relatives, provides risk management options for those with a germline pathogenic variant and excludes confirmed noncarriers (ie, negative testing when there is a known pathogenic variant in the family) from intensive surveillance and risk-reducing measures. Due to privacy laws, mutation carriers have the sole responsibility to inform blood relatives about genetic test results and advocate for genetic services. Digital health platforms can support mutation carriers during the disclosure process and provide relatives with accurate and credible information.

\section{Objectives}

The DIALOGUE study will build a bilateral research infrastructure to support collaboration and multidisciplinary initiatives around HBOC in Switzerland and Korea. The specific aims are to develop the K-CASCADE (Korean-Cancer Predisposition Cascade Genetic Testing) cohort in Korea by expanding an existing research infrastructure developed by the CASCADE Consortium in Switzerland; develop a digital health intervention to support open communication and cascade genetic testing in HBOC families, based on the linguistic and cultural adaptation of the Family Gene Toolkit; evaluate the efficacy of the digital health intervention on primary (communication of genetic test results to relatives and cascade genetic testing) and secondary (psychological distress, genetic literacy, coping, and decision making) outcomes; and explore the translatability of the platform using the reach, effectiveness, adoption, implementation, and maintenance (RE-AIM) framework.

\section{Methods}

\section{Design}

The DIALOGUE study will use a cohort design to establish the K-CASCADE in Korea and a randomized controlled trial (RCT) design to test the effects of digital health intervention in the Swiss and Korean contexts. The study will measure clinical and process outcomes in real-world conditions, including different settings, participants, and resources [34,35].

\section{Aim 1: Develop the K-CASCADE Cohort}

The K-CASCADE cohort will identify and survey mutation carriers and blood relatives as its archetype, the Swiss CASCADE cohort, using similar design, assessments, and procedures for sample identification and data collection [14]. Adult Korean men and women with $B R C A$ pathogenic variants will be invited to the K-CASCADE cohort. They will also be asked to invite their first- and second-degree relatives and their first cousins for cascade genetic screening. Similar to the Swiss CASCADE, it is envisioned that the K-CASCADE cohort will include known mutation carriers, untested relatives with unknown mutation status, and relatives who tested negative for the pathogenic variant.

\section{Aim 2: Adapt the Digital Health Intervention}

The content of the Family Gene Toolkit is driven by theory [36] and supported by empirical findings [37-41]. It is designed to address challenges related to the quantity and complexity of genetic information mutation carriers are asked to communicate with family members [42,43]. Understanding HBOC (eg, probability of mutation, prognosis, prevention, and treatment) and the accuracy of genetic testing are important for decision making. Inherited cancer risk requires ongoing management and, thus, active coping with health challenges. Mutation carriers' personal values and communication skills are important for the disclosure of genetic cancer risk. The Family Gene Toolkit embraced the above challenges and included 4 modules designed to increase knowledge of cancer genetics (module 1), provide decisional support for genetic testing to untested relatives (module 2), increase active coping with common challenges faced by HBOC families (module 3 ), and provide skills-building communication training (module 4; Figure 1). The adapted Family Gene Toolkit will include the 4 original modules and a fifth module about the management of cancer risk based on recommendations from the National Comprehensive Cancer Network [44]. 
Figure 1. Examples from the Family Gene Toolkit.

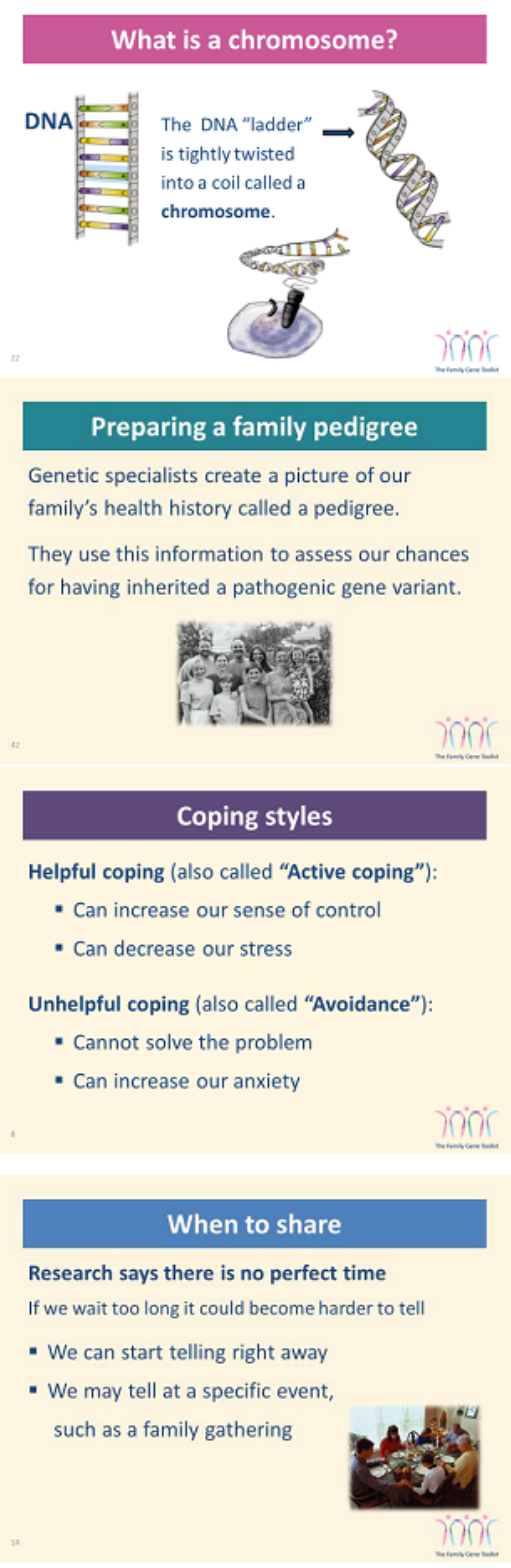

The research team will create tailored messages based on the linguistic and cultural adaptations of the modules. Tailoring is a process that fits the message to meet one's personal needs and characteristics, rather than targeting group criteria $[45,46]$. Tailored messages improve whether and how one listens to a message and its impact on behavior change. Shallow tailoring involves elements of appearance (eg, female or male mutation carriers), whereas deep tailoring involves more complex elements of relevance (eg, coping style). Adaptation of the Family Gene Toolkit involves elements of both shallow and deep tailoring based on preintervention assessments of participants' characteristics such as sex, affected with cancer versus cancer-free, and tendency to rely more on a specific coping style. The research team will use readily available e-learning products with different tailored messages, multiple interactions and assessments, and a device-agnostic interface for the adaptation of the Family Gene Toolkit. Messages will be developed in English and translated at the eighth-grade reading level while considering Swiss and Korean legislation,

\section{Chromosomes and genes come in pairs}

Human cells, like breast cells, have 46 chromosomes

The 46 chromosomes are grouped into 23 pairs

- One comes from the mother (red)

- One comes from the father (blue)

This means that genes also come in pairs

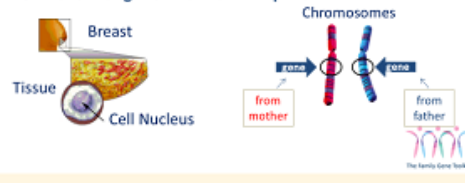

Important point!

Finding a mutation does not mean that we will definitely get cancer.

It only means that we have a higher chance of getting cancer.

\section{Relieve unpleasant feelings}

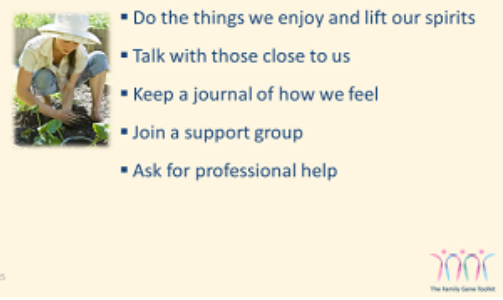

Open communication

Open family communication will help us:

- View our cancer risk as a shared health problem

- Get support from one another

- Work as a team to lower our risk

- Cope better with cancer risk

- Reduce our stress level

- Make our family stronger and healthier

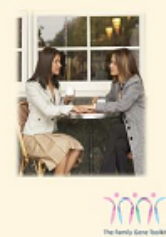

health insurance policy, cultural values, and national languages. Swiss and Korean stakeholders will review the content of the adapted Family Gene Toolkit and identify the required modifications by providing feedback on word choices, sensitivity of messages, and appearance. Mini focus groups and individual interviews with clinicians involved in genetic consultations will evaluate the prototype of each module and the tailoring elements. Focus groups with Swiss and Korean HBOC mutation carriers and relatives will provide suggestions to enhance the comprehensibility, usefulness, acceptability, and feasibility of the intervention. Feedback from clinicians and HBOC families will help in further refining each module and the tailored messages.

Assessing the usability of the adapted Family Gene Toolkit involves task-oriented assignments about the most important functions and features of the website as well as the ease and user-friendliness of navigation. Participants will think aloud while navigating each module and complete each task [47]. 
They will also evaluate the tailored messages for readability and comprehension.

Swiss and Korean participants will complete the 5 modules at their own pace, but within a timeframe of 4 weeks after they first engage with the platform. The 4-week interval enables information assimilation and adequate time to reflect and act based on tailored messages while providing a controlled learning environment. Feedback will be based on baseline responses, including tailored advice about improvements that can be made.

Consistent with testing real-world alternatives [48], the DIALOGUE study will provide a comparison website with targeted (generic) information. The comparison website will mimic the structure and functions of an existing website [49]. The adapted Family Gene Toolkit and the comparison website will be technically implemented in the same system that will collect baseline and follow-up data, randomize participants, deliver the intervention and the comparison website, track access and use of the platform, and provide a user-friendly experience to participants.

\section{Aim 3: Evaluate Intervention Efficacy on Primary and Secondary Outcomes}

A cluster RCT will evaluate the magnitude of intervention effects as compared with the comparison website. Randomization will occur at the family level, that is, after baseline data collection, the digital health intervention will randomly assign mutation carriers to either intervention arm, stratifying for country. Invited relatives will be automatically directed to the same arm as the mutation carrier. All study participants will complete a survey at baseline $\left(\mathrm{T}_{1}\right)$ before the intervention and again at 2 months $\left(\mathrm{T}_{2}\right)$ and 6 months $\left(\mathrm{T}_{3}\right)$ after the intervention. The 2- and 6-month follow-up time points will assess the short-term and long-term effects in line with our previous studies $[33,50]$.

\section{Aim 4: Explore Intervention Translatability}

The implementation and dissemination of the adapted Family Gene Toolkit will be evaluated based on the constructs of the
RE-AIM framework [51] at the individual and organizational levels.

\section{Settings}

The DIALOGUE study involves oncology and genetic testing centers of the Swiss CASCADE Consortium from 3 linguistic regions of Switzerland (German-, French-, and Italian-speaking) and similar settings in Korea, eg, Severance Hospital, Seoul, and the National Cancer Center, Goyang. Settings ensure diversity in hospital characteristics (eg, general or advanced level) and geographic location to increase sample representativeness and generalizability.

\section{Sample and Sample Size}

The DIALOGUE study targets individuals who have been identified through genetic testing as carrying a $B R C A$ pathogenic variant (proband) and their blood relatives. Textbox 1 describes the inclusion criteria for the probands and relatives. Eligible probands will be females and males (expected female-to-male ratio $=4: 1$ ) and their first- and second-degree relatives (parents, siblings, offspring, aunts, uncles, nieces, nephews, and grandparents) and their first cousins. Participants may have a cancer diagnosis (expected breast-to-ovarian cancer ratio=5:1) or they may be cancer-free. Individuals who tested positive for a variant of uncertain significance and mutation carriers without any blood relatives, spouses, and partners are excluded because cascade genetic testing does not apply to them. We also exclude individuals who tested positive for a non-BRCA pathogenic variant because of the current variation in the implementation of panel testing among the different sites, which will likely influence the recruitment of participants with non- $B R C A$ mutations. The study will only include adults because hereditary cancer risk assessment is not recommended for children. The study will also exclude vulnerable participants, such as critically ill patients and those living in nursing homes, to avoid increasing the subject burden and provide surveillance recommendations to participants who are not able to follow through the program. 
Textbox 1. Inclusion criteria.

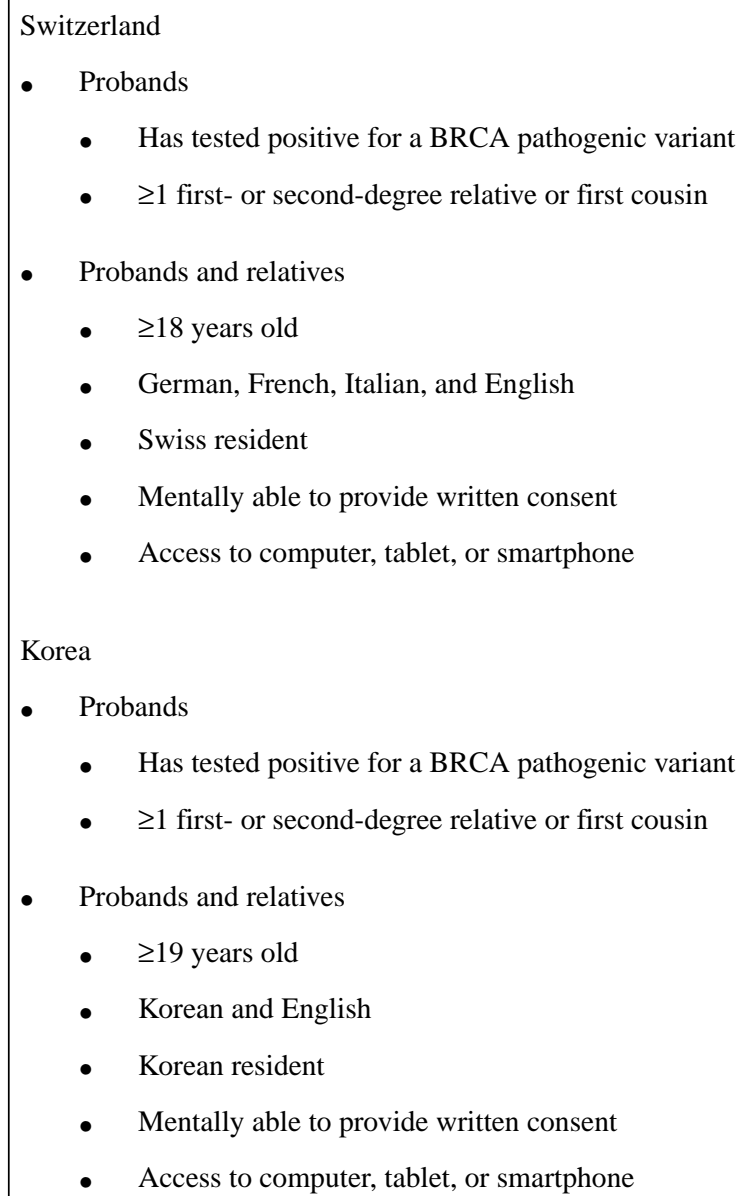

\section{K-CASCADE Cohort}

Estimates of sample accessibility follow consultations with the medical directors of clinical sites and assume average HBOC prevalence rates of $5 \%$ for both countries. There are approximately 90 new mutation carriers per year from the clinical centers affiliated with the Swiss CASCADE Consortium. Data from the Swiss CASCADE cohort indicate that it is feasible to recruit approximately $50 \%$ of the probands from each clinical site. Each proband is willing to invite an average of 4 relatives, with a response rate of $50 \%$ among relatives. In Korea, with 5 participating hospitals, 540 individuals are expected to enter the K-CASCADE cohort over 3 years (6 individuals per month $\times 12$ months $\times 3$ years $\times 5$ hospitals, $50 \%$ participation rate).

\section{Intervention Adaptation}

A purposeful sample of 20-24 participants (10-12 mutation carriers and 10-12 relatives) per linguistic region will participate in individual interviews and/or mini focus groups in each country. There will be homogeneity within members of each focus group, but the samples will be diversified in terms of demographics (eg, sex) and clinical history (eg, affected with cancer vs cancer-free) among groups. Mini focus groups or interviews will be conducted with a convenience sample of 6-10 expert clinicians involved in genetic consultation in each country. Mini focus groups allow more time to share experiences and encourage greater in-depth information and insights. The adapted Family Gene Toolkit will be tested for usability and acceptability with 5 new mutation carriers and/or relatives per linguistic region [52,53].

\section{Intervention Efficacy}

The cluster RCT will invite 114 probands to have a total of 104 evaluable subjects ( 52 for each website). This sample size would allow detecting whether using the adapted Family Gene Toolkit or the comparison website would increase the proportion of informed relatives by $25 \%$ with a statistical power of $80 \%$, a significance level of 5\%, and a dropout rate of $9.6 \%$ (11/114). We estimated the distribution of the proportion of relatives and dropout rates from our previous studies [14,50]. Less than $10.5 \%$ (12/114) of potential participants have no relatives, and less than $10.5 \%(12 / 114)$ have no access to a computer, tablet, or smartphone, making them ineligible for the study. We expect to recruit and retain the final sample of 114 probands over 18 months.

\section{Intervention Translatability}

This step involves assessing the potential for implementing the adapted Family Gene Toolkit in real-world conditions. RE-AIM dimensions will be assessed from participating and nonparticipating mutation carriers, relatives, and providers throughout the study. 


\section{Recruitment and Procedures}

\section{K-CASCADE Cohort}

The opportunity to participate in the K-CASCADE cohort will be advertised through the KOHBRA network, the Ovarian Cancer and Genetics study group, and other clinical sites. Recruitment procedures for Korean probands and relatives will follow steps and procedures similar to those outlined for the Swiss CASCADE cohort [14]. In short, index cases (first person in the family with the pathogenic variant) identified in participating centers will be invited to participate in the study by collaborating clinicians and through patient advertisements posted in the clinics. Potential participants will also be able to view information on the study website. Individuals carrying a $B R C A$ pathogenic variant, and if they have at least one eligible relative based on pedigree data, will meet study recruiters to ask questions and provide written consent. To alleviate ethical concerns associated with contacting blood relatives without their explicit consent, the K-CASCADE cohort will approach them through probands, targeting only relatives the proband is willing to contact. This recruitment method is used by the Swiss CASCADE cohort and in previous family-based studies with very good recruitment outcomes [39,54]. Relatives agreeing to participate will also provide written consent. In the consent form, probands and relatives will indicate their willingness to invite additional relatives to the K-CASCADE, be contacted once a year for 5 years and provide updated information about their health, participate in a focus group or individual interview for the adaptation of the Family Gene Toolkit in Korean, and participate in an RCT for testing the effects of the adapted Family Gene Toolkit. Probands and relatives may participate in all or some of the study steps previously described.

Probands and relatives will provide baseline assessments via a URL link to the digital health intervention and a unique passcode. A second prompt will be sent 2 weeks later. If there is no response to the second contact, study recruiters will contact the participants by phone. Relatives will also provide written consent, and they will receive a URL with a unique passcode. The Swiss CASCADE platform will facilitate data collection in both countries to maintain the consistency and accuracy of data entry, data management, and analyses. Korean respondents will $\log$ on as K-CASCADE participants to provide survey data.

\section{Intervention Adaptation}

Participants will be recruited through the Swiss CASCADE cohort and through flyers posted in the affiliated Korean institutions and clinics. After obtaining consent, focus groups or individual interviews will be organized at an easily accessible site and in participants' language. Focus groups will be coded by 2 members of the team in each country and linguistic region and will be audiotaped with participants' explicit consent. Participants will be asked to think aloud while viewing electronic mockups of the intervention and while navigating a final version of the digital health intervention. The latter sessions will be videotaped.

Clinicians involved in genetic consultations will be identified through the CASCADE Consortium in Switzerland; through the Schweizerischen Arbeitsgemeinschaft für Klinische
Krebsforschung, Network for Cancer Predisposition Testing and Counseling in Switzerland; and through the KOHBRA network in Korea. They will be recruited via email and/or invitation letters and will also provide consent. Semistructured exploratory questions will elicit their opinions on structural barriers to HBOC cascade genetic testing. At a later stage, they will also view a nearly final version of the digital health intervention and will provide feedback. Sessions will be audiotaped and videotaped with clinicians' consent.

\section{Intervention Efficacy}

After they complete the baseline questionnaires $\left(\mathrm{T}_{1}\right)$, probands (index case) in both countries who agree to participate in an RCT and test the effects of the adapted Family Gene Toolkit will be emailed a unique URL link and passcode allowing them access to the digital health intervention. Furthermore, they will be able to $\log$ in and review the intervention modules multiple times using the same URL link and passcode. The system will randomize participants in a 1:1 ratio to either the digital health intervention or the comparison website. Stratification by country (Switzerland vs Korea) will be facilitated with different URL links for participants from each country. Participants will receive weekly email or text alerts, encouraging them to visit the website and complete viewing of the contents of the digital health intervention within 4 weeks. They will also receive email or text alerts to complete a knowledge quiz, an exercise for value clarification related to genetic testing, and a family communication rubric that will be included in the content of the different modules. Participants randomized to the comparison website will receive 1 email alert 2 weeks after they engage with the website. Relatives will be allocated to the same study arm as the respective proband and will also receive a URL link and a unique passcode. Relatives will first be asked to complete a consent form and then to complete the baseline survey, after which they will have access to either the adapted Family Gene Toolkit or the comparison.

Primary and secondary outcomes will be assessed at 2 months $\left(\mathrm{T}_{2}\right)$ and 6 months $\left(\mathrm{T}_{3}\right)$ after the intervention. We selected the 2- and 6-month follow-up time points to measure the short-term and long-term intervention effects, in line with our previous studies $[33,50]$. To minimize the attrition rate, if a response has not been received within 2 weeks from the time participants receive the URL link to the follow-up survey, then the study personnel will make 3 attempts to contact them by email or phone and encourage them to complete the survey.

\section{Measures and Outcomes}

\section{K-CASCADE}

The core questions of the Swiss CASCADE cohort [14] constitute the basic measurements for the K-CASCADE. Instruments are purchased (if not available for free) and will be translated into Korean (if not available) following the World Health Organization's translation guidelines. The baseline survey covers cancer diagnoses and surveillance, use of and experience with genetic testing (for testers and nontesters), communication with health care providers, and satisfaction with cancer genetic services. It assesses information about prophylactic surgeries; epidemiological data about personal, 
reproductive, and family history of breast and ovarian cancer; and modifiable lifestyle risk factors (smoking, drinking, physical activity, etc). The baseline survey also assesses demographic characteristics and psychosocial variables, for example, the fear of cancer recurrence and self-efficacy to use services, which constitute the basis for creating the tailored messages provided by the adapted Family Gene Toolkit. These instruments are listed in Table 1. The Korean survey will be pilot tested with 10 study participants for comprehension and accuracy.

Table 1. Demographics and psychosocial characteristics.

\begin{tabular}{|c|c|c|c|c|c|}
\hline \multirow[t]{2}{*}{ Variables } & \multirow[t]{2}{*}{ Instruments } & \multirow[t]{2}{*}{ Cronbach $\alpha$} & \multirow{2}{*}{$\begin{array}{l}\text { Test-retest } \\
\text { reliability }\end{array}$} & \multicolumn{2}{|c|}{ Assessment } \\
\hline & & & & Baseline & Follow-up \\
\hline $\begin{array}{l}\text { Demographics, personal, and family } \\
\text { cancer history }\end{array}$ & Self-report [55] & $-^{\mathrm{a}}$ & - & $\checkmark^{\mathrm{b}}$ & \\
\hline \multicolumn{6}{|l|}{ Tailoring variables } \\
\hline $\begin{array}{l}\text { Degree of relationship between } \\
\text { proband-relatives (eg, first de- } \\
\text { gree) }\end{array}$ & Self-report & $\mathrm{N} / \mathrm{A}^{\mathrm{c}}$ & N/A & $\checkmark$ & \\
\hline $\begin{array}{l}\text { Fear of cancer recurrence (for } \\
\text { patients) }\end{array}$ & $\begin{array}{l}\text { Concerns About Recurrence Scale [56], } 4 \text { items, } \\
\text { 7-point Likert scale }\end{array}$ & .93 & 0.91 & $\checkmark$ & \\
\hline $\begin{array}{l}\text { Self-efficacy dealing with cancer } \\
\text { (for patients) }\end{array}$ & $\begin{array}{l}\text { Self-efficacy-HBOC }{ }^{\mathrm{d}} \text {-related cancer [57], } 14 \\
\text { items, 7-point Likert scale }\end{array}$ & .80 & 0.71 & $\checkmark$ & \\
\hline $\begin{array}{l}\text { Self-efficacy using genetic ser- } \\
\text { vices }\end{array}$ & 1 item, 7-point Likert scale & N/A & N/A & $\checkmark$ & \\
\hline Family support & $\begin{array}{l}\text { Family Support in Illness [58], } 10 \text { items, 7-point } \\
\text { Likert scale }\end{array}$ & .86 & 0.83 & $\checkmark$ & \\
\hline Family hardiness & $\begin{array}{l}\text { Family Hardness Index [59], } 20 \text { items, 7-point } \\
\text { Likert scale }\end{array}$ & .90 & 0.82 & $\checkmark$ & \\
\hline $\begin{array}{l}\text { Satisfaction with genetic counsel- } \\
\text { ing (for tested individuals) }\end{array}$ & $\begin{array}{l}\text { Multidimensional Impact of Cancer Risk Assess- } \\
\text { ment [60], } 19 \text { items, 7-point Likert scale }\end{array}$ & .81 & - & $\checkmark$ & \\
\hline $\begin{array}{l}\text { Barriers and facilitators for genet- } \\
\text { ic services }\end{array}$ & $\begin{array}{l}\text { Barriers and facilitators for genetic services [61], } \\
11 \text { items, multiple choice }\end{array}$ & N/A & N/A & $\checkmark$ & \\
\hline
\end{tabular}

${ }^{\mathrm{a}}$ Not available.

${ }^{b}$ The variable will be assessed at the specific time frame.

${ }^{\mathrm{c}} \mathrm{N} / \mathrm{A}$ : not applicable.

${ }^{\mathrm{d}}$ HBOC: hereditary breast and ovarian cancer.

\section{Intervention Adaptation}

A trained moderator will ask focus group participants to answer semistructured exploratory questions designed to elicit their opinions on the most pressing issues for family communication, using appropriate probe questions to explore potential cultural interpretations. The interview guide explores issues around family communication that took place during the genetic consultation, decision making related to the disclosure of test results to relatives, and attitudes toward using digital health platforms. Participants will also rate their satisfaction with the content, format, and appearance of the website. Assessing intervention feasibility also involves assessing the number of modules accessed, time spent on each module, and the utilization of links, which are automatically recorded on the website.

\section{Intervention Efficacy}

Data to evaluate the magnitude of intervention effects will be assessed using the instruments listed in Table 2. These have strong psychometric properties and have been used in previous studies on patients with cancer. Most of these instruments have been translated into and validated in German, French, and Italian and will be translated into and validated in Korean. Primary and secondary outcomes are assessed at the 2-month and 6-month follow-up surveys. Satisfaction with the intervention and acceptability will be assessed at the 2-month follow-up with questions about intervention usefulness, ease of use, clarity, appropriate length, level of detail, relevance, and interest with a 7 -item survey (Likert scale ranging from $1=$ low to $7=$ high) $[62,63]$. 
Table 2. Instruments to assess primary and secondary outcomes.

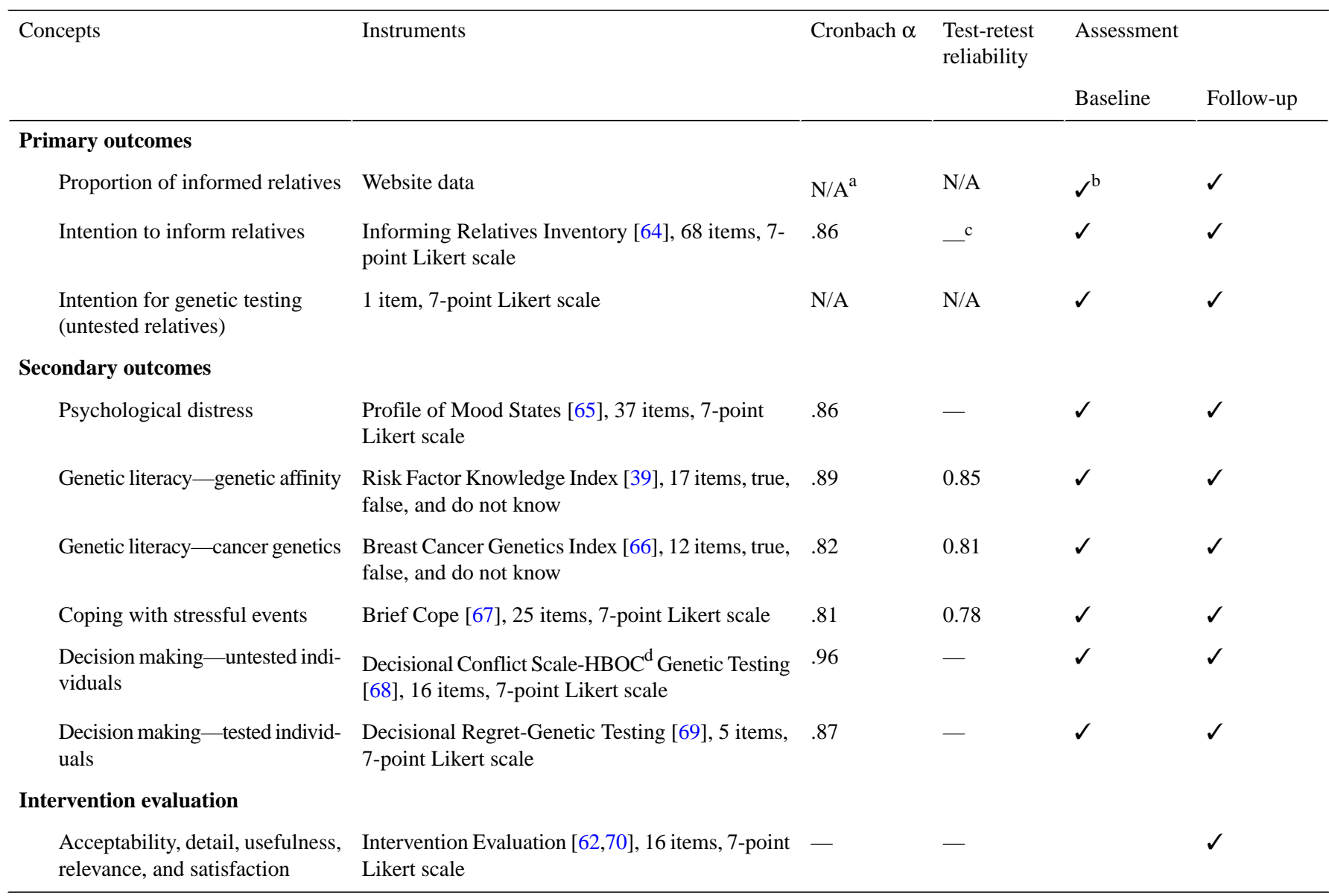

${ }^{\mathrm{a}} \mathrm{N} / \mathrm{A}$ : not applicable.

${ }^{\mathrm{b}}$ The variable will be assessed at the specific time frame.

${ }^{\mathrm{c}}$ Not available.

${ }^{\mathrm{d}}$ HBOC: hereditary breast and ovarian cancer.

\section{Intervention Translatability}

Textbox 2 outlines RE-AIM outcomes to be assessed, which will help in evaluating the potential for a broader implementation and dissemination of the digital health intervention. 
Textbox 2. Reach, effectiveness, adoption, implementation, and maintenance outcomes assessed in the study.

Reach (individual)

- Response rate of mutation carriers and relatives

- Number of probands and relatives accessing the website

- Demographic, linguistic characteristics, and region

- Response rate to K-CASCADE (Korean-Cancer Predisposition Cascade Genetic Testing)

Effectiveness (individual)

- Assess the number of times participants accessed each module

- Assess the number of relative invites initiated through the website

- Evaluate the acceptability, interest, usefulness, level of detail, relevance, and satisfaction follow-up survey

Adoption (setting, staff, and organization)

- Number of clinicians and new settings willing to participate in the study

- Diversity (geographic, linguistic, etc) in participating settings

Implementation (setting, staff, and organization)

- Monitor referrals of mutation carriers from different clinical sites

- Evaluate the cost for adapting modules for other hereditary cancer syndromes (eg, Lynch syndrome)

Maintenance (individual and setting)

- Assess resources needed to maintain the website

- $\quad$ Assess the number of visits per month per year

\section{Data Management and Data Analyses}

\section{K-CASCADE Cohort}

Korean participants' data entered in the Swiss CASCADE platform will be available for descriptive and comparative analyses, using epidemiological and psychosocial data along with coded and nonidentified clinical data. Existing clinical data from Severance Hospital, stored in the Clinical Research Analysis Portal, will also be accessed for participants who provide additional consent. At year 4, the accrued data from Korean women will be used in conjunction with clinical data for comparative analyses with the Swiss CASCADE cohort.

\section{Intervention Adaptation}

The mini focus groups or interviews with HBOC families and clinicians will be audiorecorded with participants' consent and transcribed verbatim, using codes to protect individual identification. Transcripts will be reviewed by the research team, and content will be analyzed using an iterative process of reading transcripts, coding, and comparing the data to identify salient themes. Two members of the research team in each country will also review the videotapes obtained from usability testing and the think aloud protocol. They will confirm that there are no functional errors on the website, color schemes and graphical images are well received, participants can navigate through various sections of the website with ease, the layout accurately conveys information, and the program works as expected. Data regarding acceptability will be analyzed using descriptive statistics.

\section{Intervention Efficacy}

The efficacy cluster RCT will use pre- and postintervention data from baseline $\left(\mathrm{T}_{1}\right)$ and follow-up $\left(\mathrm{T}_{2}\right.$ and $\left.\mathrm{T}_{3}\right)$ surveys. Data values will be checked for validity (within the appropriate range) using histograms and box plots and corrected whenever possible. Many items are a part of multi-item scales and are anticipated to correlate with each other. Scales will be tested for internal consistency reliability with Swiss and Korean participants using principal component analysis and Cronbach $\alpha$ coefficients. Scales with Cronbach $\alpha$ values of .71 and higher will be used. Multiple imputation or other techniques will address missing data if they exceed 5\% of observations and if they are less than $25 \%$ for each specific scale. Data from participants who withdraw will be kept to ensure internal validity.

Primary outcomes will be calculated with the Wilcoxon-Mann-Whitney test to compare the proportions of informed relatives per study arm. Other primary and secondary outcomes and metadata from the automatic recording of website activity will be analyzed using descriptive statistics. Descriptive analyses will include calculating the means and frequencies of key variables and subject descriptors (eg, genetic testing). This will include tabulating counts and frequencies of variables, including demographics and personal cancer history. Bivariate analyses (using the chi-square test for differences in proportions and $t$ test for differences in means) will assess the associations between demographic factors and clinical characteristics. The following comparisons will be made: between probands and relatives, between men and women, between patients with cancer and cancer-free individuals, between participants with 
children and those with no children, between different age groups, and between patients with different cancer diagnoses. A detailed methodology for summaries and statistical analyses will be documented in a statistical analysis plan. This plan will be finalized before database closure and will be under version control at the Clinical Trial Unit, University Hospital Basel. All analyses will be conducted using the statistical software R [71], using two-sided statistical tests and confidence intervals with confidence levels $\alpha=5 \%$ and $(100 \%-\alpha)=95 \%$, respectively. Deviations from planned analyses are not foreseen. The study statistician will review and approve any deviations from the original statistical plan.

\section{Intervention Translatability}

Data exploring the RE-AIM of the digital health intervention will be analyzed using qualitative and quantitative methods. Narrative data obtained from mini-interviews will be audiorecorded, transcribed verbatim, and analyzed for common themes. Descriptive analyses will include calculating the means and frequencies of the key variables and subject descriptors. Bivariate analyses (chi-square test for differences in proportions and $t$ test for differences in means) will compare key variables between participants and nonparticipants.

\section{Results}

The DIALOGUE study, including the development of the K-CASCADE cohort in Korea, was funded in October 2019. It is projected that data collection will be completed by January 2023, and results will be published in fall 2023.

\section{Discussion}

\section{Principal Findings}

The need to enhance family communication around HBOC has been documented in the literature since mid-2000 [72-74], followed approximately 10 years later by scientific calls to enhance cancer predisposition cascade genetic testing [75-77]. The DIALOGUE study is a resource-effective international research platform that proposes building a tailored, interactive website to reach a large number of HBOC families and enhance cancer predisposition cascade genetic screening, presumably requiring only a fraction of the cost and required clinician time compared with previous approaches. Developing the
K-CASCADE cohort will link together the expertise of an eminent network of HBOC scholars and clinicians that will benefit both countries and serve as a model for potential expansion to other countries and in other language contexts. The cross-cultural adaptation of the Family Gene Toolkit will help explore the similarities and differences in communication practices among HBOC families in the Swiss and Korean contexts, potentially providing important information about the Korean and Swiss contexts that affect HBOC discourse [78]. This comparison will also reveal context-specific characteristics regarding the influence of the health care system, insurance coverage, and socioeconomic aspects on the application of genetic knowledge that can provide useful information for adapting other digital health solutions within the Swiss and Korean contexts. The goal of the adapted Family Gene Toolkit is to attend to the needs of diverse families, including the function of different members, and cultural and linguistic backgrounds. It is thus important to consider digital health technologies as sociocultural products with a need for an adaptation to specific local contexts and a critical reflection about how they may affect local perceptions of illness [78]. The final product will likely be more cost-effective and will expedite scaling-up, dissemination, and implementation, given the existing strong clinical partnerships within each country.

\section{Conclusions}

The adaptation and implementation of culturally sensitive, digitally based health interventions that enhance the understanding of genetic cancer risk are extremely timely and relevant, given the expansion of genetic testing technology, the falling costs of genetic testing, and the increased pressure for the integration of genetic knowledge in routine clinical care. Genetic testing for hereditary susceptibility to disease has received increasing attention among the health care community and at the individual, familial, and international levels. The DIALOGUE study will contribute to the development of high-quality comprehensive support systems that enhance the counseling process and facilitate informed decision making by minimizing conflict and distress and making resources available in culturally appropriate ways. Ultimately, the study contributes to a broader dissemination of genetic information and helps in expanding the public health understanding of the impact of new technologies on risk stratification and disease management.

\section{Acknowledgments}

The Swiss National Science Foundation (IZKSZ3_188408/1) and the Korean National Research Foundation provided funding (2019K1A3A1A14063080) for a Swiss-Korean bilateral research collaboration. The authors would like to acknowledge PD Lars G Hemkens, MD, MPH, Senior Scientist in Clinical Epidemiology, Department of Clinical Research, University of Basel, for his input during the development of the grant application.

\section{Conflicts of Interest}

None declared.

\section{References}

1. Ferlay J, Steliarova-Foucher E, Lortet-Tieulent J, Rosso S, Coebergh J, Comber H, et al. Cancer incidence and mortality patterns in Europe: estimates for 40 countries in 2012. Eur J Cancer 2013 Apr;49(6):1374-1403 [FREE Full text] [doi: 10.1016/j.ejca.2012.12.027] [Medline: 23485231] 
2. Bray F, Ferlay J, Soerjomataram I, Siegel RL, Torre LA, Jemal A. Global cancer statistics 2018: GLOBOCAN estimates of incidence and mortality worldwide for 36 cancers in 185 countries. CA Cancer J Clin 2018 Nov;68(6):394-424 [FREE Full text] [doi: 10.3322/caac.21492] [Medline: $\underline{30207593]}$

3. DeSantis CE, Ma J, Gaudet MM, Newman LA, Miller KD, Goding Sauer A, et al. Breast cancer statistics, 2019. CA Cancer J Clin 2019 Nov;69(6):438-451 [ [FREE Full text] [doi: 10.3322/caac.21583] [Medline: 31577379]

4. Sopik V. International variation in breast cancer incidence and mortality in young women. Breast Cancer Res Treat 2021 Apr;186(2):497-507. [doi: 10.1007/s10549-020-06003-8] [Medline: 33145697]

5. Yip CH, Evans DG, Agarwal G, Buccimazza I, Kwong A, Morant R, et al. Global disparities in breast cancer genetics testing, counselling and management. World J Surg 2019 May 4;43(5):1264-1270. [doi: 10.1007/s00268-018-04897-6] [Medline: 30610270]

6. Park EH, Min SY, Kim Z, Yoon CS, Jung K, Nam SJ, Korean Breast Cancer Society. Basic facts of breast cancer in Korea in 2014: the 10-year overall survival progress. J Breast Cancer 2017 Mar;20(1):1-11 [FREE Full text] [doi: 10.4048/jbc.2017.20.1.1] [Medline: 28382089]

7. Park B, Hopper JL, Win AK, Dowty JG, Sung HK, Ahn C, KOHBRA Study Group. Reproductive factors as risk modifiers of breast cancer in mutation carriers and high-risk non-carriers. Oncotarget 2017 Nov 24;8(60):102110-102118 [FREE Full text] [doi: 10.18632/oncotarget.22193] [Medline: 29254229]

8. Schoumacher F, Glaus A, Mueller H, Eppenberger U, Bolliger B, Senn H. BRCA1/2 mutations in Swiss patients with familial or early-onset breast and ovarian cancer. Swiss Med Wkly. 2001 Apr 21. URL: https://pubmed.ncbi.nlm.nih.gov/ 11400546/ [accessed 2021-05-06]

9. Greenberg S, Buys SS, Edwards SL, Espinel W, Fraser A, Gammon A, et al. Population prevalence of individuals meeting criteria for hereditary breast and ovarian cancer testing. Cancer Med 2019 Nov;8(15):6789-6798 [FREE Full text] [doi: 10.1002/cam4.2534] [Medline: 31531966]

10. Grosse SD, Rogowski WH, Ross LF, Cornel MC, Dondorp WJ, Khoury MJ. Population screening for genetic disorders in the 21st century: evidence, economics, and ethics. Public Health Genomics 2010;13(2):106-115. [doi: 10.1159/000226594] [Medline: 19556749]

11. Clain E, Trosman JR, Douglas MP, Weldon CB, Phillips KA. Availability and payer coverage of BRCA1/2 tests and gene panels. Nat Biotechnol 2015 Sep;33(9):900-902 [FREE Full text] [doi: 10.1038/nbt.3322] [Medline: 26348951]

12. Katz SJ, Kurian AW, Morrow M. Treatment decision making and genetic testing for breast cancer: mainstreaming mutations. J Am Med Assoc 2015 Sep 08;314(10):997-998. [doi: 10.1001/jama.2015.8088] [Medline: 26203642]

13. Khoury MJ, Evans JP. A public health perspective on a national precision medicine cohort: balancing long-term knowledge generation with early health benefit. J Am Med Assoc 2015 Jun 02;313(21):2117-2118 [FREE Full text] [doi: 10.1001/jama.2015.3382] [Medline: 26034952]

14. Katapodi MC, Viassolo V, Caiata-Zufferey M, Nikolaidis C, Bührer-Landolt R, Buerki N, et al. Cancer predisposition cascade screening for hereditary breast/ovarian cancer and lynch syndromes in Switzerland: study protocol. JMIR Res Protoc 2017 Sep 20;6(9):e184 [FREE Full text] [doi: 10.2196/resprot.8138] [Medline: 28931501]

15. Nikolaidis C, Ming C, Pedrazzani C, van der Horst T, Kaiser-Grolimund A, Ademi Z, for the CASCADE Consortium. Challenges and opportunities for cancer predisposition cascade screening for hereditary breast and ovarian cancer and lynch syndrome in Switzerland: findings from an international workshop. Public Health Genomics 2018;21(3-4):121-132. [doi: 10.1159/000496495] [Medline: $\underline{\text { 30695780] }}$

16. Kang E, Park SK, Lee JW, Kim Z, Noh W, Jung Y, et al. KOHBRA BRCA risk calculator (KOHCal): a model for predicting BRCA1 and BRCA2 mutations in Korean breast cancer patients. J Hum Genet 2016 May;61(5):365-371. [doi: 10.1038/jhg.2015.164] [Medline: 26763880]

17. Kang E, Seong M, Park SK, Lee JW, Lee J, Kim LS, Korean Hereditary Breast Cancer Study Group. The prevalence and spectrum of BRCA1 and BRCA2 mutations in Korean population: recent update of the Korean Hereditary Breast Cancer (KOHBRA) study. Breast Cancer Res Treat 2015 May;151(1):157-168. [doi: 10.1007/s10549-015-3377-4] [Medline: 25863477]

18. Caiata-Zufferey M, Pagani O, Cina V, Membrez V, Taborelli M, Unger S, et al. Challenges in managing genetic cancer risk: a long-term qualitative study of unaffected women carrying BRCA1/BRCA2 mutations. Genet Med 2015 Sep;17(9):726-732. [doi: 10.1038/gim.2014.183] [Medline: 25503500]

19. Fadda M, Chappuis PO, Katapodi MC, Pagani O, Monnerat C, Membrez V, et al. Physicians communicating with women at genetic risk of breast and ovarian cancer: are we in the middle of the ford between contradictory messages and unshared decision making? PLoS One 2020;15(10):e0240054 [FREE Full text] [doi: 10.1371/journal.pone.0240054] [Medline: 33031463]

20. Kim H, Kim SY, Joly Y. South Korea: in the midst of a privacy reform centered on data sharing. Hum Genet 2018 Aug;137(8):627-635 [FREE Full text] [doi: 10.1007/s00439-018-1920-1] [Medline: 30121900]

21. Caswell-Jin JL, Gupta T, Hall E, Petrovchich IM, Mills MA, Kingham KE, et al. Racial/ethnic differences in multiple-gene sequencing results for hereditary cancer risk. Genet Med 2018 Feb;20(2):234-239. [doi: 10.1038/gim.2017.96] [Medline: 28749474] 
22. Fraser L, Bramald S, Chapman C, Chu C, Cornelius V, Douglas F, et al. What motivates interest in attending a familial cancer genetics clinic? Familial Cancer 2001;2(3/4):159-168. [doi: 10.1023/b:fame.0000004621.38109.16] [Medline: 14707527]

23. Kang E, Park SK, Kim KS, Choi DH, Nam S, Paik NS, et al. Communication with family members about positive BRCA1/2 genetic test results in Korean hereditary breast cancer families. J Genet Med 2011 Dec 31;8(2):105-112. [doi: 10.5734/jgm.2011.8.2.105]

24. van den Heuvel LM, Stemkens D, van Zelst-Stams WA, Willeboordse F, Christiaans I. How to inform at-risk relatives? Attitudes of 1379 Dutch patients, relatives, and members of the general population. J Genet Couns 2020 Oct;29(5):786-799 [FREE Full text] [doi: 10.1002/jgc4.1206] [Medline: $\underline{\text { 31889383] }}$

25. Ratnayake P, Wakefield CE, Meiser B, Suthers G, Price MA, Duffy J, Kathleen Cuningham National Consortium for Research into Familial Breast Cancer, et al. An exploration of the communication preferences regarding genetic testing in individuals from families with identified breast/ovarian cancer mutations. Fam Cancer 2011 Mar;10(1):97-105. [doi: 10.1007/s10689-010-9383-0] [Medline: 20878485]

26. Bowen DJ, Hyams T, Laurino M, Woolley T, Cohen S, Leppig KA, et al. Development of Familytalk: an intervention to support communication and educate families about colorectal cancer risk. J Cancer Educ 2020 Jun;35(3):470-478. [doi: 10.1007/s13187-019-1484-3] [Medline: 30737640]

27. Birch PH. Interactive e-counselling for genetics pre-test decisions: where are we now? Clin Genet 2015 Mar;87(3):209-217. [doi: $10.1111 /$ cge.12430] [Medline: 24828354]

28. Syrowatka A, Krömker D, Meguerditchian AN, Tamblyn R. Features of computer-based decision aids: systematic review, thematic synthesis, and meta-analyses. J Med Internet Res 2016 Jan 26;18(1):e20 [FREE Full text] [doi: 10.2196/jmir.4982] [Medline: 26813512]

29. Vrečar I, Hristovski D, Peterlin B. Telegenetics: an update on availability and use of telemedicine in clinical genetics service. J Med Syst 2017 Feb;41(2):21. [doi: 10.1007/s10916-016-0666-3] [Medline: 27987158]

30. Otten E, Birnie E, Ranchor AV, van Langen IM. Telegenetics use in presymptomatic genetic counselling: patient evaluations on satisfaction and quality of care. Eur J Hum Genet 2016 Apr;24(4):513-520 [FREE Full text] [doi: 10.1038/ejhg.2015.164] [Medline: 26173963]

31. Buchanan AH, Datta SK, Skinner CS, Hollowell GP, Beresford HF, Freeland T, et al. Randomized trial of telegenetics vs. In-person cancer genetic counseling: cost, patient satisfaction and attendance. J Genet Couns 2015 Dec;24(6):961-970 [FREE Full text] [doi: 10.1007/s10897-015-9836-6] [Medline: 25833335]

32. Gaieski JB, Patrick-Miller L, Egleston BL, Maxwell KN, Walser S, DiGiovanni L, et al. Research participants' experiences with return of genetic research results and preferences for web-based alternatives. Mol Genet Genomic Med 2019 Sep;7(9):e898 [FREE Full text] [doi: 10.1002/mgg3.898] [Medline: 31376244]

33. Katapodi MC, Jung M, Schafenacker AM, Milliron KJ, Mendelsohn-Victor KE, Merajver SD, et al. Development of a web-based family intervention for BRCA carriers and their biological relatives: acceptability, feasibility, and usability study. JMIR Cancer 2018 Apr 13;4(1):e7 [FREE Full text] [doi: 10.2196/cancer.9210] [Medline: 29653920]

34. Battaglia C, Glasgow RE. Pragmatic dissemination and implementation research models, methods and measures and their relevance for nursing research. Nurs Outlook 2018 Sep;66(5):430-445. [doi: 10.1016/j.outlook.2018.06.007] [Medline: $\underline{\text { 30093135] }}$

35. Curran GM, Bauer M, Mittman B, Pyne JM, Stetler C. Effectiveness-implementation hybrid designs: combining elements of clinical effectiveness and implementation research to enhance public health impact. Med Care 2012 Mar;50(3):217-226 [FREE Full text] [doi: 10.1097/MLR.0b013e3182408812] [Medline: 22310560]

36. Folkman S, Moskowitz JT. Stress, appraisal, and coping. In: Anderson NB, editor. Encyclopedia of Health and Behavior. Thousand Oaks, California, United States: Sage Publications Inc; 2004:1927-1935.

37. Katapodi MC, Dodd MJ, Lee KA, Facione NC. Underestimation of breast cancer risk: influence on screening behavior. Oncol Nurs Forum 2009 May;36(3):306-314. [doi: 10.1188/09.ONF.306-314] [Medline: 19403452]

38. Katapodi MC, Lee KA, Facione NC, Dodd MJ. Predictors of perceived breast cancer risk and the relation between perceived risk and breast cancer screening: a meta-analytic review. Prev Med 2004 Apr;38(4):388-402. [doi: 10.1016/j.ypmed.2003.11.012] [Medline: 15020172 ]

39. Katapodi MC, Northouse LL, Milliron KJ, Liu G, Merajver SD. Individual and family characteristics associated with BRCA1/2 genetic testing in high-risk families. Psychooncology 2013 Jun;22(6):1336-1343. [doi: 10.1002/pon.3139] [Medline: 22826208]

40. Northouse LL, Katapodi MC, Song L, Zhang L, Mood DW. Interventions with family caregivers of cancer patients: meta-analysis of randomized trials. CA Cancer J Clin 2010;60(5):317-339 [FREE Full text] [doi: 10.3322/caac.20081] [Medline: 20709946]

41. Northouse L, Schafenacker A, Barr KL, Katapodi M, Yoon H, Brittain K, et al. A tailored Web-based psychoeducational intervention for cancer patients and their family caregivers. Cancer Nurs 2014;37(5):321-330 [FREE Full text] [doi: 10.1097/NCC.0000000000000159] [Medline: 24945270]

42. Barry MJ, Edgman-Levitan S. Shared decision making--pinnacle of patient-centered care. N Engl J Med 2012 Mar 01;366(9):780-781. [doi: 10.1056/NEJMp1109283] [Medline: 22375967] 
43. Kohler JN, Turbitt E, Biesecker BB. Personal utility in genomic testing: a systematic literature review. Eur J Hum Genet 2017 Jun;25(6):662-668 [FREE Full text] [doi: 10.1038/ejhg.2017.10] [Medline: 28295040]

44. Daly MB, Pilarski R, Berry M, Buys SS, Farmer M, Friedman S, et al. NCCN guidelines insights: genetic/familial high-risk assessment: breast and ovarian, version 2. J Natl Compr Canc Netw 2017 Jan;15(1):9-20 [FREE Full text] [doi: 10.6004/jnccn.2017.0003] [Medline: 28040716]

45. Hawkins RP, Kreuter M, Resnicow K, Fishbein M, Dijkstra A. Understanding tailoring in communicating about health. Health Educ Res 2008 Jun 01;23(3):454-466 [FREE Full text] [doi: 10.1093/her/cyn004] [Medline: 18349033]

46. Kreuter MW, Wray RJ. Tailored and targeted health communication: strategies for enhancing information relevance. Am J Health Behav 2003;27 Suppl 3:227-232. [doi: 10.5993/ajhb.27.1.s3.6] [Medline: 14672383]

47. Kushniruk AW, Patel VL. Cognitive and usability engineering methods for the evaluation of clinical information systems. J Biomed Inform 2004 Feb;37(1):56-76 [FREE Full text] [doi: 10.1016/j.jbi.2004.01.003] [Medline: 15016386]

48. Glasgow RE, Fisher L, Strycker LA, Hessler D, Toobert DJ, King DK, et al. Minimal intervention needed for change: definition, use, and value for improving health and health research. Transl Behav Med 2014 Mar;4(1):26-33 [FREE Full text] [doi: 10.1007/s13142-013-0232-1] [Medline: 24653774]

49. Empowering families with hereditary cancers through communication and education. Kintalk. URL: https://kintalk.org/ [accessed 2020-07-11]

50. Katapodi MC, Ming C, Northouse LL, Duffy SA, Duquette D, Mendelsohn-Victor KE, et al. Genetic testing and surveillance of young breast cancer survivors and blood relatives: a cluster randomized trial. Cancers (Basel) 2020 Sep 05;12(9):2526 [FREE Full text] [doi: 10.3390/cancers12092526] [Medline: 32899538]

51. RE-AIM framework. URL: https://www.re-aim.org/ [accessed 2020-11-05]

52. Bastien JM. Usability testing: a review of some methodological and technical aspects of the method. Int J Med Inform 2010 Apr;79(4):18-23. [doi: 10.1016/j.ijmedinf.2008.12.004] [Medline: 19345139]

53. Nielsen J. Usability Engineering. Burlington, Massachusetts, United States: Morgan Kaufmann; 1994:1-362.

54. Katapodi MC, Duquette D, Yang JJ, Mendelsohn-Victor K, Anderson B, Nikolaidis C, et al. Recruiting families at risk for hereditary breast and ovarian cancer from a statewide cancer registry: a methodological study. Cancer Causes Control 2017 Mar;28(3):191-201. [doi: 10.1007/s10552-017-0858-2] [Medline: 28197806]

55. Behavioral risk factor surveillance system questionnaire. Centers for Disease Control and Prevention. 2001. URL: https:/ /www.cdc.gov/brfss/questionnaires/pdf-ques/2001brfss.pdf [accessed 2019-01-18]

56. Vickberg SMJ. The Concerns About Recurrence Scale (CARS): a systematic measure of women's fears about the possibility of breast cancer recurrence. Ann Behav Med 2003;25(1):16-24. [doi: 10.1207/S15324796ABM2501 03] [Medline: 12581932]

57. Champion VL, Ziner KW, Monahan PO, Stump TE, Cella D, Smith LG, et al. Development and psychometric testing of a breast cancer survivor self-efficacy scale. Oncol Nurs Forum 2013 Nov;40(6):403-410 [FREE Full text] [doi: 10.1188/13.ONF.E403-E410] [Medline: 24161644]

58. Katapodi MC, Facione NC, Miaskowski C, Dodd MJ, Waters C. The influence of social support on breast cancer screening in a multicultural community sample. Oncol Nurs Forum 2002 Jun;29(5):845-852. [doi: 10.1188/02.0NF.845-852] [Medline: 12058159]

59. McCubbin HI, Thompson AI, McCubbin MA. Family Assessment: Resiliency, Coping and Adaptation (Inventories for Research and Practice). Madison: University of Wisconsin, Center for Excellence in Family Studies; 1996:1-912.

60. Cella D, Hughes C, Peterman A, Chang C, Peshkin BN, Schwartz MD, et al. A brief assessment of concerns associated with genetic testing for cancer: the Multidimensional Impact of Cancer Risk Assessment (MICRA) questionnaire. Health Psychol 2002 Nov;21(6):564-572. [Medline: 12433008 ]

61. Anderson B, McLosky J, Wasilevich E, Lyon-Callo S, Duquette D, Copeland G. Barriers and facilitators for utilization of genetic counseling and risk assessment services in young female breast cancer survivors. J Cancer Epidemiol 2012;2012:298745 [FREE Full text] [doi: 10.1155/2012/298745] [Medline: 23150731]

62. Durand M, Witt J, Joseph-Williams N, Newcombe RG, Politi MC, Sivell S, et al. Minimum standards for the certification of patient decision support interventions: feasibility and application. Patient Educ Couns 2015 Apr;98(4):462-468. [doi: 10.1016/j.pec.2014.12.009] [Medline: 25577469]

63. Hoffman AS, Llewellyn-Thomas HA, Tosteson AN, O'Connor AM, Volk RJ, Tomek IM, et al. Launching a virtual decision lab: development and field-testing of a web-based patient decision support research platform. BMC Med Inform Decis Mak 2014 Dec 12;14:112 [FREE Full text] [doi: 10.1186/s12911-014-0112-8] [Medline: 25495552]

64. de Geus E, Aalfs CM, Menko FH, Sijmons RH, Verdam MG, de Haes HC, et al. Development of the Informing Relatives Inventory (IRI): assessing index patients' knowledge, motivation and self-efficacy regarding the disclosure of hereditary cancer risk information to relatives. Int J Behav Med 2015 Aug;22(4):551-560. [doi: 10.1007/s12529-014-9455-x] [Medline: 25515913]

65. Curran SL, Andrykowski MA, Studts JL. Short Form of the Profile of Mood States (POMS-SF): psychometric information. Psychol Assess 1995;7(1):80-83. [doi: 10.1037/1040-3590.7.1.80] 
66. Wang C, Gonzalez R, Milliron KJ, Strecher VJ, Merajver SD. Genetic counseling for BRCA1/2: a randomized controlled trial of two strategies to facilitate the education and counseling process. Am J Med Genet A 2005 Apr 01;134A(1):66-73. [doi: 10.1002/ajmg.a.30577] [Medline: 15690408]

67. Carver CS. You want to measure coping but your protocol's too long: consider the brief COPE. Int J Behav Med 1997;4(1):92-100. [doi: 10.1207/s15327558ijbm0401 6] [Medline: 16250744$]$

68. Katapodi M, Munro M, Pierce P, Williams R. Psychometric testing of the decisional conflict scale genetic testing hereditary breast and ovarian cancer. Nurse Res 2011;60(6):368-377. [doi: 10.1097/nnr.0b013e3182337dad]

69. Brehaut JC, O'Connor AM, Wood TJ, Hack TF, Siminoff L, Gordon E, et al. Validation of a decision regret scale. Med Decis Making 2003;23(4):281-292. [doi: 10.1177/0272989X03256005] [Medline: 12926578]

70. Northouse LL, Walker J, Schafenacker A, Mood D, Mellon S, Galvin E, et al. A family-based program of care for women with recurrent breast cancer and their family members. Oncol Nurs Forum 2002;29(10):1411-1419. [doi:

10.1188/02.ONF.1411-1419] [Medline: 12432412]

71. R-4.0.5 for Windows (32/64 bit). URL: https://cran.r-project.org/bin/windows/base/ [accessed 2020-11-07]

72. Claes E, Evers-Kiebooms G, Boogaerts A, Decruyenaere M, Denayer L, Legius E. Communication with close and distant relatives in the context of genetic testing for hereditary breast and ovarian cancer in cancer patients. Am J Med Genet A 2003 Jan 01;116A(1):11-19. [doi: 10.1002/ajmg.a.10868] [Medline: 12476445]

73. Kenen R, Arden-Jones A, Eeles R. We are talking, but are they listening? Communication patterns in families with a history of breast/ovarian cancer (HBOC). Psychooncology 2004 May;13(5):335-345. [doi: 10.1002/pon.745] [Medline: 15133774]

74. Nycum G, Avard D, Knoppers BM. Factors influencing intrafamilial communication of hereditary breast and ovarian cancer genetic information. Eur J Hum Genet 2009 Jul 25;17(7):872-880 [FREE Full text] [doi: 10.1038/ejhg.2009.33] [Medline: 19319160]

75. George R, Kovak K, Cox SL. Aligning policy to promote cascade genetic screening for prevention and early diagnosis of heritable diseases. J Genet Couns 2015 Jun;24(3):388-399. [doi: 10.1007/s10897-014-9805-5] [Medline: 25577298]

76. Modell S, Greendale K, Citrin T, Kardia S. Expert and advocacy group consensus findings on the horizon of public health genetic testing. Healthcare (Basel) 2016 Jan 27;4(1):14 [FREE Full text] [doi: 10.3390/healthcare4010014] [Medline: $\underline{27417602]}$

77. Walker JL, Powell CB, Chen L, Carter J, Bae Jump VL, Parker LP, et al. Society of Gynecologic Oncology recommendations for the prevention of ovarian cancer. Cancer 2015 Jul 01;121(13):2108-2120 [FREE Full text] [doi: 10.1002/cncr.29321] [Medline: 25820366]

78. Burke NJ, Mathews HF. Returning to earth: setting a global agenda for the anthropology of cancer. Med Anthropol 2017 Apr;36(3):179-186. [doi: 10.1080/01459740.2016.1255611] [Medline: 27854127]
Abbreviations
CASCADE: Cancer Predisposition Cascade Genetic Testing
HBOC: hereditary breast and ovarian cancer
K-CASCADE: Korean-Cancer Predisposition Cascade Genetic Testing
KOHBRA: Korean Hereditary Breast Cancer
RCT: randomized controlled trial
RE-AIM: reach, effectiveness, adoption, implementation, and maintenance

Edited by G Eysenbach; submitted 04.12.20; peer-reviewed by S Suggs, R Pozzar; comments to author 01.01.21; revised version
received 09.02.21; accepted 25.02.21; published 11.06.21
Please cite as:
Kim S, Aceti M, Baroutsou V, Bürki N, Caiata-Zufferey M, Cattaneo M, Chappuis PO, Ciorba FM, Graffeo-Galbiati R,
Heinzelmann-Schwarz V, Jeong J, Jung MM, Kim SW, Kim J, Lim MC, Ming C, Monnerat C, Park HS, Park SH, Pedrazzani CA,
Rabaglio M, Ryu JM, Saccilotto R, Wieser S, Zürrer-Härdi U, Katapodi MC
Using a Tailored Digital Health Intervention for Family Communication and Cascade Genetic Testing in Swiss and Korean Families
With Hereditary Breast and Ovarian Cancer: Protocol for the DIALOGUE Study
JMIR Res Protoc 2021; 10(6):e26264
URL: https://www.researchprotocols.org/2021/6/e26264
doi: $10.2196 / 26264$
PMID:

(C) Sue Kim, Monica Aceti, Vasiliki Baroutsou, Nicole Bürki, Maria Caiata-Zufferey, Marco Cattaneo, Pierre O Chappuis, Florina M Ciorba, Rossella Graffeo-Galbiati, Viola Heinzelmann-Schwarz, Joon Jeong, MiSook M Jung, Sung-Won Kim, Jisun Kim, Myong Cheol Lim, Chang Ming, Christian Monnerat, Hyung Seok Park, Sang Hyung Park, Carla A Pedrazzani, Manuela Rabaglio, 
Jai Min Ryu, Ramon Saccilotto, Simon Wieser, Ursina Zürrer-Härdi, Maria C Katapodi. Originally published in JMIR Research Protocols (https://www.researchprotocols.org), 11.06.2021. This is an open-access article distributed under the terms of the Creative Commons Attribution License (https://creativecommons.org/licenses/by/4.0/), which permits unrestricted use, distribution, and reproduction in any medium, provided the original work, first published in JMIR Research Protocols, is properly cited. The complete bibliographic information, a link to the original publication on https://www.researchprotocols.org, as well as this copyright and license information must be included. 